\section{Endotoxin and cancer}

\author{
Endotoxina e câncer
}

Jessica I. Lundin ${ }^{1}$

Harvey Checkoway $^{1}$
This article was originally published by Environ Health Perspect 117:13441350 (2009).doi:10.1289/ ehp.0800439 available via http://dx.doi.org/ [Online 7 $M$ ay 2009] and is part of the scientific collaboration between Cien Saude Colet and EHP.

${ }^{1}$ Department of Environmental and Occupational $\mathrm{H}$ ealth Sciences, U niversity of Washington, School of Public Health, Office E179E, Box 357234, 1959 NE Pacific St., Seattle, WA 98195 USA.

jlundin2@.u.washington.edu
Abstract Exposure to endotoxin, a component of gram-negative bacterial cell walls, is widespread in many industrial settings and in the ambient environment. Heavy-exposure environments include livestock farms, cotton textile facilities, and saw mills. In this article, we review epidemiologic, clinical trial, and experimental studies pertinent to the hypothesis that endotoxin prevents cancer. Since the 1970s, epidemiologic studies of cotton textile and other endotoxin-exposed occupational groups have consistently demonstrated reduced lung cancer risks. Experimental animal toxicology research and some limited therapeutic trials in cancer patients offer additional support for an anticarcinogenic potential. The underlying biological mechanisms of anticarcinogenesis are not entirely understood but are thought to involve the recruitment and activation of immune cells and proinflammatory mediators (e.g., tumor necrosis factor $\alpha$ and interleukin-1 and 6). In view of the current state of knowledge, it would be premature to recommend endotoxin as a cancer-chemopreventive agent. H owever, further epidemiologic and experimental investigations that can clarify further dose-effect and exposure-timing relations could have substantial public health and basic biomedical benefits. Key words Cancer, Carcinogenesis, Endotoxin, Epidemiology, Lipopolysaccharide, LPS, Lung cancer, O ccupational epidemiology
Resumo A exposição à endotoxina, componente deparedes celulares bacterianas gram-negativas, é muito comum em plantas industriais e no meio ambiente. Ambientes de alta exposição incluem fazen das de criação de animais, instalações têxteis dealgodão emoinhos. N este artigo, revemos estudos experimentais, epidemiológicos e ensaios clínicos sobre a hipótese de quea endotoxina previne o câncer. Desde os anos 70, estudos epidemiológicos em têxteis de algodão e outros grupos ocupacionais expostos à endotoxina demonstram redução no risco de câncer de pulmão. Pesquisa experimental de toxicologia animal e ensaios terapêuticos limitados em pacientes com câncer dão suporte para um potencial anticarcinogênico. Os mecanismos biológicos anticarcinogênicos de base ainda não são completamente compreendidos, mas acredita-se que incluem recrutamento e ativação de células imunológicas e mediadores pró-inflamatórios (ex.: fator de necrose tumoral á e interleucina-1 e-6). D evido ao estági o atual de conhecimento, seria prematuro recomendar a endotoxina como agente quimiopreventivo. Porém, pesqui sas epidemiológicas e experimentais que esclareçam relações de dosagem-efeito e exposição-re lações temporais podem trazer benefícios para a saúde pública ea biomedicina básica.

Palavras-chave Câncer, Carcinogênese, Endotoxina, Epidemiologia, Lipopolissacarídeo, LPS, Câncer de pulmão, Epidemiologia ocupacional 
Endotoxins areintegral components of the outer membrane of gram-negative bacteria cell walls, composed of proteins, lipids, and lipopolysaccharide (LPS), which are released when bacteria Iyse $^{1}$. LPS is considered to be responsiblefor most of the biological properties of bacterial endotoxins, particularly the lipid component (lipid A, a phosphoglycolipid) 2,3. Endotoxins are a conta minant of various organic dusts and other environmen-tal media that support gram-negative bacterial growth ${ }^{4-7}$. The bacterial constituents are continuously shed into our surrounding environment; consequently, exposure to endotoxin is extremely widespread.

The Limulus amoebocyte lysate (LAL) assay for environmental endotoxin levels was adopted as the standard assay of endotoxin detection by the U.S. Food and Drug Administration in the $1980 s^{6}$. This assay is based on the activation of a clotting enzyme in the lysate. Endotoxin levels are often expressed as endotoxin units (EU; 1 EU $\sim 0.1 \mathrm{ng}$, depending on the refer-ence standard), or as concentration of endotoxin per milligram of dust or per cubic meter of air. Of note, LAL tests are not internation-ally standardized, and measurements may vary among laboratories ${ }^{6}$.

Of particular interest from a health effects perspectivearethemoreintense exposures experienced in numerous manufacturing and agricultural settings throughout the world. Substantial endotoxin exposure occurs in agricultural work, garbage handling, sewage treatment, and incineration industries, textileindustries (particularly cotton products factories), and saw mills, and to a lesser degree in occupations with exposures to certain types of water-based metal working fluids and in cigarettefactories, fiberglass production facilities, and paper mills, among others ${ }^{6,8-13}$. Cotton factories in the Shanghai textile industry have been documented to havehigh endotoxin exposure concentrations ${ }^{8}$. By way of illustration, the mean of the endotoxin levels that have been measured in representative cotton factorieswas $366 \mathrm{EU} / \mathrm{m} 3$ (range, 44-1,871 EU/m3) ${ }^{14}$. Additionally, reported mean endo-toxin concentrations of 40 and $48 \mathrm{EU} / \mathrm{m} 3$ have been reported among municipal waste management work$\mathrm{ers}^{15,16}$. In the agricultural industry, an overall mean endotoxin concentration of $230 \mathrm{EU} / \mathrm{m} 3$ has been reported, with mean measurements of $2,700 \mathrm{EU} / \mathrm{m} 3$ (range, $96-42,300 \mathrm{EU} / \mathrm{m} 3$ ) in the grain, seeds, and legume primary production sector and 1,190 EU/m3 (range, 62-8,120 EU/m3) in the primary animal production sector ${ }^{15}$. Other studies havereported endotoxin levels for live- stock farmers ranging from 11 to $159 \mathrm{EU} / \mathrm{m} 3$ and field crop and fruit farming exposure levels ranging from low to $>1,500 \mathrm{EU} / \mathrm{m}^{12}$, and an exposure concentration of $140 \mathrm{EU} / \mathrm{m} 3$ among swine farmers ${ }^{17}$.

Endotoxin isubiquitous in the environment, although the exposure in occupational settings, frequently $>100 \mathrm{ng} / \mathrm{m} 3$, is more intensethan exposure in the home, $<1 \mathrm{ng} / \mathrm{m}^{18}$. Nonetheless, adverse health effects have been observed at endotoxin levels as low as $0.2 \mathrm{ng} / \mathrm{m}^{19}$. The human health effects of acute exposure to endotoxin include sepsis; clinical symptoms such as fever, shaking chills, and septic shock; and, at lower doses, toxic pneumonitis, lung function decrements, and respiratory symptoms, such as byssinosis ("M onday morning chest tightness") 20,21. Chronic exposures have been related to the risk of developing nonatopic chronic obstructive pulmonary diseases ${ }^{19,22,23}$ and to the severity of asth$\mathrm{ma}^{24}$. In contrast, numerous studies have demonstrated seemingly protective effects of environmental endotoxin exposure on atopic asthma risk and allergy development in early childhood ${ }^{25,26}$, and atopy in adults ${ }^{5,27,28}$. As we discuss in some detail in this article, an inverse association with endotoxin exposure and the risk of cancer of the lung, and potentially other cancer end points, has consistently been demonstrated.

More than a century of clinical, laboratory, and epidemiologic research demonstratesthat endotoxin has antitumor properties ${ }^{29,30}$, but an understanding of the underlying mechanisms, and the subsequent development of an effective therapeutic application of endotoxin, has yet to beelucidated. We reviewed current and historical literatureidentified in M edline ${ }^{31}$ electronic database, 1973-2008, using combinations of search key words such as endotoxin, LPS, epidemiology, lung, cancer, farmer, textile, and cotton. The text and citations of all identified supporting articles were reviewed with a particular focus on lung cancer, cotton textileworkers [studies of textile workers that did not specify type of textile (i.e., cotton) were not reviewed], and studies of farmers by type of farming (dairy, crop, etc.). In addition a M edline search of publications from 1990 to 2008 was performed that reviewed the underlying mechanism of action so as to best describe the paradoxical understanding and association of the immune system response to endotoxin exposure and cancer.

In this review wediscuss thehistorical and current understanding of the association of endotoxin exposureand cancer, therapeutic uses/treatment 
of cancer with LPS, epidemiologic studies of endotoxin exposure, and theunderlying mechanisms to explain thehuman studies.

\section{Endotoxin and cancer}

\section{Early experiments}

In thelate 19th century, William B. Coley, with the assistance of established anecdotal theories of the beneficial effect of fever on tumors ${ }^{32}$, recognized regression and, in some cases, necrosis of tumors in advanced cancer patients suffering concomitant bacterial infections. Coley went on to successfully treat cancer in terminally ill patients by injecting mixed bacterial toxins in and around the tumors ${ }^{33}$. Despite the successes, this treatment was discontinued because the anticancer effect in patients was not consistent and re peated injections caused severe side effects, such as high fever and chills, that were not yet understood $^{34}$. In the early 1940s, LPS was identified as theactive ingredient in Coley's "bacterial vaccine", and the antitumor effects of the bacterial polysaccharide were successfully demonstrated in vivo ${ }^{35,36}$. When isolated LPS was found to be ineffective as an antitumor agent in culture, it was determined that theeffects weremediated by hostdependent mechanisms. Almost three decades later, tumor necrosis factor $\alpha$ (TNF- $\alpha$ ) was determined to bethe effectiveagent with antitumor properties ${ }^{37}$. By the mid-1980s therapeutic uses of TNF- $\alpha$ were being tested, but the therapy was less effective than hoped and caused undesired side effects, such as headache, nausea, vomiting, fever, hypotension, and diarrhea ${ }^{34,38,39}$. Around this sametime, it was discovered that TN F- $\alpha$ was identical to cachectin, a mediator responsiblefor cachexia associated with sepsi $3^{38,40}$. The adverse effects of TNF- $\alpha$ were quickly accepted as limita tions to its direct use as an antitumor agent ${ }^{34,40}$.

\section{Treatment of cancer with LPS}

Laboratory studies have succesffully demonstrated therapeutic effects when administering LPS, or synthetic lipid A molecule, including inhibition of tumor size and growth ${ }^{41-44}$. Morita et al. ${ }^{44}$ demonstrated this effect to be dose dependent. Additionally, an increased survival timehas been noted for miceinfected with cancer cells that have been inoculated with LPS ${ }^{41,45}$. An inverse dose-response association was demonstrated on the survival of cancer-bearing rats that were ad- ministered a synthetic anal ogue of lipid $A^{43}$. Furthermore, antigenic memory has been demonstrated on mice with tumor cells planted intracranially; the mice with previous LPS-eradicated tumors showed increased survival compared with those without previous tumors ${ }^{46}$.

Subsequently small clinical trials administering LPS, or alipid A analog, havebeen performed. Cancer remission and disease stabilization have been demonstrated in cancer patients $s^{47-50}$. However, clinical toxicities have been unavoidable, even with the pretreatment of ibuprofen ${ }^{47,48,50}$.

\section{Epidemiologic studies}

of endotoxin exposure and cancer risk

\section{Lung cancer}

Cancer risks, particularly lung cancer, have been investigated in relation to occupational endotoxin exposures (Table 1). Cotton textile and farming industries have been a particular focus of epidemiologic research because of the substantial endotoxin exposurein these occupational settings, so we review these two industries in detail. Findings from early occupational cohort studies demonstrated reduced risks for lung cancer among cotton textileworkers in the United States ${ }^{51,52}$ and the United Kingdom ${ }^{53}$, particularly in those with longer durations of employment. These results were regarded as somewhat surprising when first observed. Lower than expected lung cancer risks were subsequently reported from a cohort study conducted among women textile workers in Shanghai ${ }^{8,54}$, a separate, unrelated, case-control study of both men and women in the cotton textile industry in Shanghai ${ }^{55}$, cotton textile workers in Poland ${ }^{56}$, and a study of Italian cotton mill workers ${ }^{57}$. Slightly elevated lung cancer risks were noted in Lithuanian and Finnish cohorts of cotton textile workers ${ }^{10,58}$; however, extended followup of the Lithuanian cohort, by 5 years, indicated significantly reduced lung cancer risk among male workers employed for at least 10 years ${ }^{59}$, and the reported risk in the Finnish cohort was based on three cases. In a meta-analysis of studies of cotton workerspublished during or before 1990, and of studies published during or before 2002, lung cancer risk was significantly reduced ${ }^{60}$. Of note, therisk estimatefor lung cancer was closer to unity when the more recent studies were included. The authors of the meta-analysis hypothesized this may bedueto a lowering of dust concentration in the workplace in recent years.

Protection for lung cancer has been demonstrated to be similar among different types of 
farming ${ }^{61,62}$, although most studies reviewed demonstrated a greater protective effect in livestock farmers, specifically dairy farmers, compared with orchard/crop farmers ${ }^{63-68}$; Lange et al. ${ }^{64}$ demonstrated that the risk difference was statistically significant. Additionally, crop farmer exposures are predominantly during warmer harvest months ( $\sim 4$ months) and may not be representative of theactual annual dose, whereas the exposure experience of livestock farmers occurs 12 months a year ${ }^{12,15,64}$. For these reasons, and for simplification of discussion by selecting a homogeneous population, studies of dairy farmers are the focus of this review.

Inverse associations with respiratory cancers have consistently been observed among dairy farmers ${ }^{63,66-71}$ (Table 1). In a cohort of Italian dairy farmers, an inverse association with increased number of dairy cattle on the farm was demonstrated; a significant inverse trend $(p=$ 0.001 ) was reported for farmers with more recent exposures ${ }^{66,69}$. Lung and bronchus cancer risksweresignificantly lower among Finnish dairy farmers who continued farming at the time of follow-up ( 20-year lag time) than for those that had quit farming, and risk of lung cancer was elevated for farmers who changed their production type to a crop or to beef cattle from the beginning of the study to follow-up, compared with those who continued as dairy farmers $\mathrm{s}^{63}$. An earlier follow-up from this same Finnish Farm Register base cohort also demonstrated a significant decreasein lung and bronchus cancer mortalities among dairy farmers and reported the risk was lowest among farmers with at least 10 dairy $\operatorname{cows}^{67}$. Lung cancer mortality and incidence has also been shown to be significantly reduced in livestock farmers in the U.S. and Iceland, respectively ${ }^{64,72}$.

Only limited epidemiologic evidenceis available from investigations of lung cancer risks in nontextile and nonfarming occupations that entail endotoxin exposure, yet thefindings aregenerally consistent with an anticarcinogenic effect.

Table 1. Lung cancer outcomes associated with occupational exposure to endotoxin.

\begin{tabular}{|c|c|c|c|c|c|c|}
\hline \multirow[b]{3}{*}{ Location } & \multirow[b]{3}{*}{ Study } & \multicolumn{5}{|c|}{ Outcomes } \\
\hline & & \multicolumn{3}{|c|}{ Overall } & \multicolumn{2}{|c|}{ Highest exposure } \\
\hline & & Sex & $\begin{array}{l}\mathrm{N} 0 \text { of } \\
\text { cases }\end{array}$ & $\begin{array}{c}\text { RR } \\
(95 \% \mathrm{Cl})\end{array}$ & $\begin{array}{l}\mathrm{N} 0 \text { of } \\
\text { cases }\end{array}$ & $\begin{array}{c}\text { RR } \\
(95 \% \mathrm{Cl})\end{array}$ \\
\hline \multicolumn{7}{|c|}{ Cotton textile workers } \\
\hline China & Astrakianakis et al. 8 a & $\mathrm{F}$ & -- & -- & 74 & $0.70(0.52-0.95)$ \\
\hline China & Levin et al. ${ }^{55}$ & $M, F$ & 169 & $0.7(0.6-0.9)$ & 48 & $0.8(0.5-1.3)$ \\
\hline China & Wernli et al. 54 a & $\mathrm{F}$ & 641 & $0.8(0.74-0.86)$ & 236 & $0.72(0.63-0.82)$ \\
\hline Italy & M astrangelo et al. ${ }^{57}$ & $M, F$ & 36 & $1.03(0.72-1.43)$ & 10 & $0.93(0.45-1.72)$ \\
\hline \multirow[t]{2}{*}{ Lithuania } & Kuzmickiene and Stukonis 59 & M & 70 & $0.94(0.73-1.19)$ & 2 & $0.24(0.03-0.86)$ \\
\hline & & $\mathrm{F}$ & 15 & $1.36(0.76-2.25)$ & 1 & $0.55(0.01-3.08)$ \\
\hline \multirow[t]{2}{*}{ Poland } & Szeszenia-Dabrowska et al. ${ }^{56}$ & M & 85 & $0.89(0.71-1.10)$ & 22 & $0.79(0.50-1.20)$ \\
\hline & & $\mathrm{F}$ & 12 & $0.55(0.28-0.96)$ & 9 & $0.82(0.37-1.56)$ \\
\hline UK & Hodgson and Jones ${ }^{53}$ & $M, F$ & 42 & $0.76(0.54-1.02)$ & -- & -- \\
\hline USA & Henderson and Enterlina 51 & M & 20 & $0.55(-)$ & -- & -- \\
\hline USA & Merchant and Ortmeyer 52 & M & 18 & $0.74(-)$ & 3 & $0.52(-)$ \\
\hline \multicolumn{7}{|l|}{ Dairy farme's } \\
\hline Finland & Laakkonen and Pukkala 63 b & $M, F$ & 94 & $0.51(0.42-0.62)$ & -- & -- \\
\hline \multirow[t]{2}{*}{ Finland } & Pukkala and N otkola 67 b & M & 185 & $0.5(0.4-0.5)$ & -- & -- \\
\hline & & $\mathrm{F}$ & 14 & $0.5(0.3-0.8)$ & -- & -- \\
\hline I taly & M astrangelo et al. ${ }^{69}$ & M & 75 & $0.64(0.51-0.81)$ & 7 & $0.47(0.19-0.96)$ \\
\hline $\mathrm{NZ}$ & Reit et al. 68 & M & -- & $0.66(0.48-0.92)$ & -- & -- \\
\hline USA & Stark et al. $70 \mathrm{c}$ & M & 103 & $0.52(-)$ & -- & -- \\
\hline USA & Wang et al. ${ }^{71 \mathrm{c}}$ & $\mathrm{F}$ & 21 & $0.33(0.20-0.51)$ & -- & -- \\
\hline
\end{tabular}

Abbreviations: -- : data not available; F: female; $\mathrm{M}$ : male.

${ }^{a}$ Same cohort with different characterization of exposure; ${ }^{b}$ Same base cohort with different years of follow-up; ${ }^{c}$ cohort of farm residents; $>50 \%$ were dairy farmers. 
Reduced lung cancer risks have been observed in U.S. automotive workers exposed to endotoxin from water-based metalworking fluids ${ }^{73}$. The associations were primarily attributableto exposures within 10 years of death. $M$ arkedly reduced lung cancer incidence was also observed among pesticide applicators in the Agricultural $\mathrm{H}$ ealth Study cohort in the United States, which was attributed to a low preval ence of smoking habits ${ }^{61,74}$. Pesticides were the principal focus of that study; endotoxin has not yet been investigated as a possible explanatory factor for the lung cancer deficit. A deficit in lung cancer risk was also observed in a study of more than a million Finnish men based on their self-reported longest held occupation in the 1970 national census, lagged by 20 years, with endotoxin exposure determined by an occupational exposure matrix ${ }^{75}$; a deficit was not observed in women. In contrast, a study of occupational exposures in Leningrad Province, Russia, reported a $>2$-fold greater risk of lung cancer in subjects ever occupationally exposed to cotton dust ${ }^{76}$. Of note, therisk estimate was based on six cases, and the evaluation of cumulative exposure to cotton dust in males resulted in a protective effect.

Among thestudies of endotoxin exposureand lung cancer, quantitative estimates of historical endotoxin exposures have been reconstructed for the Lithuanian ${ }^{59}$ and Shanghai 8,77 cohorts, and qualitative estimates of exposure have been estimated for Italian dairy farmers ${ }^{69}$, to enable doseresponse estimations of numerous site-specific cancers. All cohorts demonstrated a significant inverse dose response trend when evaluating endotoxin exposure by dust exposure category, cumulative cotton dust exposure, and number of dairy cattle on the farm, respectively, and lung cancer.

\section{Other cancers}

The findings to date for endotoxin exposure and risks for malignancies other than lung cancer have been limited and inconsistent. Much of therisk information on industrial exposures has been derived from the Shanghai cohort study of female textile workers. The first publication of this cohort described theoccupational cancer risk for all textileworkers, with select cancer outcomes evaluated by textile sector ${ }^{54}$. A decreased risk of most cancers was reported, with a significant decrease for esophageal, stomach, rectal, cervical, ovarian, and bladder cancers. Subsequent publications of this cohort evaluated the associ- ation of cumulative quantitative endotoxin exposure, as well as duration of occupational exposure classified by a job exposure matrix, and individual cancer end points, including liver, esophagus, stomach, rectum, pancreas, breast, brain, ovary, nasopharynx, and thyroid ${ }^{78-86}$. Notable findings from these studies include a decreased risk for cancer of the esophagus [ hazard ratio $(\mathrm{HR})=0.5 ; 95 \%$ confidence interval $(\mathrm{Cl})$, $0.2-1.1]$ and increased risk for cancer of the nasopharynx ( $\mathrm{HR}=2.5 ; 95 \% \mathrm{Cl}, 1.1-5.4)^{82,84}$.

Other cotton textile industry cohorts have been evaluated for theassociation of occupational endotoxin exposure and cancers other than the lung. Szeszenia-Dabrowska ${ }^{56}$ reported a decreased risk of digestive cancers for men and women working in spinning and weaving departments. When considering individual cancers in men, there was a suggested increased risk of coIon and liver cancers in weavers and stomach cancer in spinners, although these individual assessments were based on small numbers. Individual cancers in women showed a suggested decrease risk of rectal/anal and liver cancers and a suggested increase in gallbladder and ovarian cancers. In a Lithuanian cohort of textile workers, female workers in the spinning and weaving departments demonstrated increased risks for most individual cancers evaluated, with significant findings for breast and cervical cancers ${ }^{10}$. Other studies of cotton textile factory cohorts that defined exposureas employment in the production facility reported a decrease in breast and diges-tive cancers $\mathrm{s}^{51,53}$ and an increase in bladder, pharyngeal, and digestive cancers ${ }^{51,57}$. In a metaanalysis of 15 studies of cotton workers published during or before 1990, a nonsignificant increased risk of bladder cancer and decreased risk of digestive cancer were reported ${ }^{60}$.

Among Finnish dairy farmersthat con-tinued farming at the time of follow-up ( 20-year lag time), the risks of colon, liver, breast, bladder, and skin cancers weresignificantly decreased, and risk of lip cancer was significantly increased ${ }^{63}$. $M$ astrangel $0^{69}$ reported a decreased risk of mortality associated with most cancers evaluated in a cohort of I talian dairy farmers, with a significant decrease in esophageal, pancreatic, and bladder cancers. In a cohort of predominantly dairy farmers, female and male, in New York State, a decrease in risk was reported for most cancers, with significant decreases in risk for colon/rectum and ovarian cancers in females and cancers of the oral cavity, large intestine, and bladder in males ${ }^{70,71}$. 
Physiologic response

to endotoxin exposure and cancer risk

Various mechanistic argu-ments have been advanced regarding endo-toxin and carcinogenesis, focusing largely on complex interactions be tween the innate and adaptive immune systems ${ }^{87,88}$. Onceinternalized, LPS is bound by LPSbinding protein (LBP) and then transferred to CD 14 protein (Figure 1). The CD14-LPS complex binds to and activates the Toll-like receptors (TLRs), which are cell membrane signaling proteins located on cell surfaces of macrophages and other cells. TLR4 is the predominant receptor for endotoxin and is required for endotoxin recognition ${ }^{89}$. U pon recognition of LPS, the innate inflammatory response is initiated and proinflammatory cytokines are released, including TNF- $\alpha$, interleukin (IL)-1, and IL-6, which recruit immune cells to the site of exposure and induce the acute-phase response $e^{3,88}$. This host response is important for an effective immune system; however, overproduction of proinflammatory factors can cause en dotoxic shock. In addition, TLR activation inducesthe expression of CD 80 and CD86 on the surface of antigen-presenting cells that interact with the adaptive immune system to activate naive T-lymphocytecells ( $\mathrm{T}$ cells $)^{2,90,91}$. The maturation of helper T cells (TH) results in cellmediated (TH1) and humoral (TH2) subpopu- lations. The cytokines released by each of these cells have unique profiles and suppress the proliferation of the other subpopulation ${ }^{88}$. The immune reaction to LPS primarily activates TH 1 cells, which maximize the killing efficiency of macrophages and induce up-regulation of proinflammatory mediators ${ }^{90-92}$. Notably, antitumor activity has been related to the cytokine profile associated with a $\mathrm{TH} 1$ response, whereas the $\mathrm{TH} 2$ profile has been shown to be in effective in eradicating tumors ${ }^{93,94}$.

\section{Lung cancer}

It has been postulated that bacterial endotoxin, through immunologic mechanisms, can be protective against lung cancer. Insofar as the route of endotoxin exposure is predominantly inhalation, thelung is one of theinitial sites of immune stimulation ${ }^{6}$. Additionally, Klein et al. ${ }^{95}$ showed in a rat model that 5 min after injection of Escherichia coli, the $20 \%$ of bacteria not taken up by the liver were found in the lungs, spleen, and blood. The TH 1 response favored by LPS-activated immune cells may be a conjectured benefit to this initial site of exposure in that the TH 1 immuneresponsetends to bemorelocal ized than the TH 2 response $e^{88}$. M oreover, the lung has been shown to produce or up-regulate the production of cofactors involved in the host response, including LBP, CD 14, and TLR4, after LPS expo-

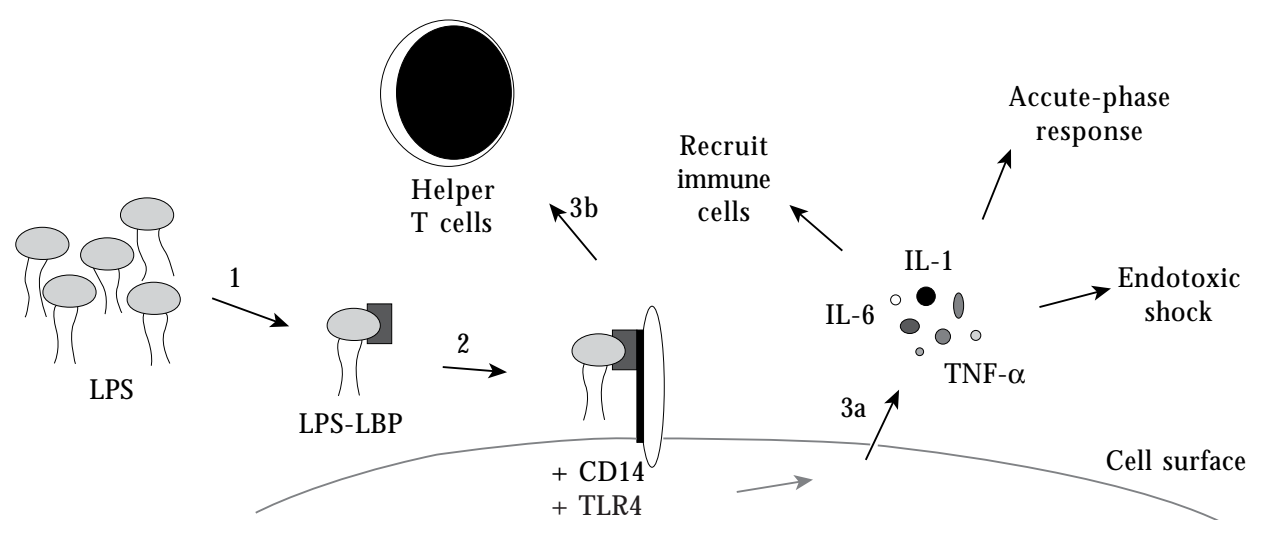

Figure 1. M echanism of host response to LPS. Once internalized, LPS is bound by LBP (1) and transferred to CD14 (2); this new complex activates TLR4, followed by initiation of the innate (3a) and adaptive (3b) immune responses. 
sure ${ }^{96-98}$. It is generally accepted that LBP is produced in the liver, but it has been shown that significant levels of LBP could be produced elsewherein the body under induced conditions, such as an inflammatory response ${ }^{98}$. In the presence of LBP, approximately 15 -fold less LPS have been reported to be required to trigger an inflammatory response, as measured using TNF- $\alpha^{99,100}$. Thereis al so consistent experimental evidencefor an increase in TNF in the bronchoal veolar lavage (BAL) fluid in guinea pigs after cotton dust exposure ${ }^{101}$, and an increase in TNF in the BAL fluid of humans after endotoxin exposure ${ }^{102-104}$ Likewise, Michel et al. ${ }^{105}$ reported a dose- dependent increase in TNF in the sputum of LPS-exposed subjects.

\section{Other cancers}

Other cancer end points have been studied, including cancers of the liver, esophagus, stomach, rectum, pancreas, breast, brain, ovary, thyroid, and nasopharynx, but not as extensively as the lung, and the findings have been inconsistent ${ }^{10,51-54,56,57,70,71,75,78-81,83-86}$. N onetheless, subsequent effects in other organ systems are plausible because cells with TLR4 receptors are widely disseminated, and elevation of systemic inflammatory mediators, including TN F- $\alpha, I L-1, I L-6$, and IL-8, has been shown after inhalation of LPS or media contaminated with endotoxin ${ }^{2,3,105-109}$. Additionally, a dose-related systemic response to inhal ed LPS in human subjects after bronchial challenges with pure LPS has been demonstrated ${ }^{105}$.

\section{Discussion: future research needs}

The individual immune response to endotoxin is a complicated result of dose, timing, poten-tial additive or synergistic effects, and geneti-cally determined responsiveness ${ }^{29}$. The health effects, including cancer outcomes associated with exposure, remain paradoxical.

Underlying biological mechanisms need to be elucidated

Insofar as endotoxin provokes an inflammatory response $e^{105,106,108,110}$, it might reasonably be anticipated that inflammation would enhance, rather than prevent, carcinogenesis $\mathrm{s}^{111-113}$. A sizable proportion of cancer deaths has been postulated to be attributable to infectious agents in which inflammation, mediated by recruitment of cytokines and growth factors to infected sites, may influence susceptibility to carcinogenesis through DNA damageand the simultaneous promotion of tissue destruction and repair ${ }^{113}$. The roles of $\mathrm{H}$. pylori (which generates endotoxin) in the etiology of adenocarcinoma of the stomach, human papillomavirus in the etiology of anogenital carcinoma, and hepatitis B or C virus in hepatocellular carcinoma arecases in point ${ }^{113-114}$. Additionally, over-stimulation of inflammatory responses can lead to severe clinical symptoms, often termed sepsis, which can lead to progressive organ failure and death ${ }^{115}$. However, in lesser doses, which may relate best to chronic low-dose occupational and environmental endotoxin exposure, the proinflammatory mediators have been shown to inhibit tumor growth and retard tumor progression $37,116-118$.

Exposure to LPS has been demon-strated to induce pathologic hyperactivity ${ }^{119}$, but a mechanism of protection from this lethal reactivity, termed endotoxin tolerance, has been speculated. Endotoxin tolerance is the unresolved phenomenon defined as an altered capacity to respond to LPS activation immediately after a first exposure; that is, when exposed to continual small doses of LPS, the same TNF response of the initial exposure does not necessarily occur with subsequent exposure ${ }^{48,50,105,109,120,121}$. This tolerance has been shown to vary by dose as well as by length of time between treatments, and is theorized to allow the host moretimeto rid the pathogen $^{48,120}$. Because this tolerance has been related to allowing a body system to endure continuous small doses without adverse symptoms, a better understanding of this mechanism may bring clarity to the relationships between endotoxin sensitivity (including acute toxic effects) and sepsis, and, possibly, between carcinogenesis and protection against cancer ${ }^{120}$.

\section{Epidemiologic corroboration}

Experimental evidence from both animal models and therapeutic trials regarding the effects of endotoxin on carcinogenic processes has not been consistent ${ }^{122,123}$, which indicates the importance of epidemiologic observations for guiding mechanistic and clinical research. Difficulties in studying endotoxin epidemiologically include the very large degree of exposure variability over timeand among study subjects, and uncertainties in the measurement, or proxy measure, of exposure ${ }^{124}$. The general pattern of endotoxin exposureand cancer that emergesfrom existing epidemiologic research is one suggestive of an anticar- 
cinogenic effect of endotoxin exposure that occurs in the lung and, perhaps, other organs. This consistency of findings has been main-tained when using job history as a proxy of exposure $\mathrm{e}^{51}$ $54,57,59,63,64,70,71$, incorporating a cumulative endotoxin exposure matrix variable $e^{8,59,73}$, and using number of dairy cattle on the farm ${ }^{69}$. N onetheless, with a few exceptions, most epidemiologic studies of endotoxin and cancer have not incorporated quantitative estimates of endotoxin exposure, which would strengthen causal arguments.

Although not unique to epidemiologic studies of endotoxin and cancer, absence of data on potentially confounding factors has been a limitation of most studies to date. Smoking status was incorporated in select analyses of endotoxin exposure and cancer and was shown to not account for the whole reduction in lung cancer risk, although the effect was exaggerated in those with low smoking habits, $8,53,61,64,66,69$. Specifically, in the study of lung cancer among Shanghai textileworkers, the inverse dose-response relation was not confounded by smoking, and importantly, the apparent protective effect was seen among both smokers and nonsmokers ${ }^{8}$. The very low prev-alence of smoking in this cohort of Chinese women workers precludes generalizability of these observation $\mathrm{s}^{54}$, thus underscoring theimportance of obtaining pertinent data on smoking and other cancer risk factors in future research.

\section{References}

1. Campbell NA, Reece JB, Urry LA, Cain ML, Wasserman SA, Minorsky PV, Jackson RB. Biology. $8^{\text {th }}$ ed. San Francisco, CA: Benjamin Cummings; 2008.

2. Hodgson JC. Endotoxin and mammalian host responses during experimental disease. J Comp Pathol 2006; 135(4):157-175.

3. Reisser D, Pance A, Jeannin JF. Mechanisms of the anti-tumoral effect of lipid A. Bioessays 2002; 24(3):284-289.

4. CDC (Centers for Disease Control and Prevention) $\mathrm{H}$ ealth concerns associated with mold in water-damaged homes after hurricanes Katrina and Rita N ew Orleans area, Louisiana, October 2005. M M W R M orb M ortal Wkly Rep 2006; 55(2):41-44.

5. Gehring U, Bischof W, Schlenvoigt G, Richter K, Fahlbusch B, Wichmann HE, Heinrich J. Exposure to house dust endotoxin and allergic sensitization in adults. Allergy 2004; 59(9):946-952.

6. Liebers V, Bruning T, Raulf-H eimsoth M. Occupational endotoxin-exposure and possible health effects on humans. Am J Indust M ed 2006; 49(6):474491.

\section{Concluding remarks}

Exposure to endotoxin isubiquitous in the environment at levels that have been shown to have physiologic effects and, in some instances, demonstrable health consequences. There is very consistent epidemiologic evidence that endotoxin is dose-related to risk reductions for lung cancer, and provocative evidence that risks for other cancers may be similarly reduced. Animal experimental research and limited therapeutic trial data are generally supportive of an anticarcinogenesis effect, and plausible biological mechanisms have been described. The public health implications of findings to date could be substantial. Nevertheless, a more extensive assessment of the role of endotoxin in the etiology of cancers of the lung and other organs is needed. Future epidemiologic and toxicologic research to elucidate more precisely dose-response relations and underlying mechanisms will need to be conducted beforeendotoxin, an agent with established noncancer toxic heal th effects, could beconsidered for widespread chemoprevention uses ${ }^{125}$.
7. Park JH, Cox-Ganser J, Rao C, Kreiss K. Fungal and endotoxin measurements in dust associated with respiratory symptoms in a water-damaged office building. Indoor Air 2006; 16(3):192-203.

8. Astrakianakis G, Seixas NS, Ray R, Camp JE, Gao $D L$, Feng Z, Li W, Wernli KJ, Fitzgibbons ED, Thomas $D B, C h e c k o w a y ~ H$. Lung cancer risk among female textile workers exposed to endotoxin. J Natl Cancer Inst 2007; 99(5):357-364.

9. CDC. What you need to know about occupational exposure to metalworking fluids. DHHS (NIOSH) Publication N 0. 98-116. Atlanta, GA: Centers for Disease Control and Prevention; 1998.

10. Kuzmickiene I, Didziapetris R, Stukonis M. Cancer incidence in the workers cohort of textile manufacturing factory in Alytus, Lithuania. J Occup Environ M ed 2004; 46(2):147-153.

11. M andryk J, Alwis KU, Hocking AD. Work-related symptoms and dose-response relationships for personal exposures and pulmonary function among woodworkers. Am J Indust M ed 1999; 35(5):481-490. 
12. Nieuwenhuijsen MJ, Noderer KS, Schenker MB, Vallyathan V, Olenchock S. Personal exposure to dust, endotoxin and crystalline silica in California agriculture. Ann Occup Hygiene 1999; 43(1):35-42.

13. Rapiti E, Sperati A, Fano V, Dell'Orco V, Forastiere F. Mortality among workers at municipal waste incinerators in Rome: a retrospective cohort study. Am J Ind M ed 1997; 31(5):659-661.

14. Astrakianakis G, Seixas N, Camp J, Smith TJ, Bartlett K, Checkoway H. Cotton dust and endotoxin levels in three Shanghai textile factories: a comparison of sam-plers. J Occup Environ Hygiene 2006; 3(8):418-427.

15. Spaan S, Wouters IM, O osting I, Doekes G, Heederik D. Exposure to inhalable dust and endotoxins in agricultural industries. J Environ M onit 2006; $8(1): 63-72$.

16. Wouters IM, Spaan S, Douwes J, Doekes G, H eederik D. Overview of personal occupational exposure levels to inhalable dust, endotoxin, $\beta(1 \rightarrow 3)$ glucan and fungal extra-cellular polysaccharides in the waste management chain. Ann Occup Hygiene 2006; 50(1):39-53.

17. Chang CW, Chung $\mathrm{H}$, Huang $\mathrm{CF}$, Su HJ. Exposure assess-ment to airborne endotoxin, dust, ammonia, hydrogen sulfide and carbon dioxide in open style swine houses. Ann Occup Hygiene 2001; 45(6):457-465.

18. Rylander R, Sorenson S, Gotoo H, Yusao K, Tanaka $\mathrm{S}$. The importance of endotoxin and glucan for symptoms in sick buildings. In: Bieva CJ, Courtois $Y$, Govaerts M, eds. Present and future of indoor air quality. Amsterdam: Elsevier Science; 1989. p. 219-226.

19. Smid T, Heederik D, Houba R, Quanjer PH. Dustand endotoxin-related respiratory effects in the animal feed industry. Am Rev Respir Dis 1992; 146(6):1474-1479.

20. Rylander R. Endotoxin in the environment: exposure and effects. J Endotoxin Res 2002; 8(4):241-252.

21. Rylander R. Endotoxin and occupational airway disease. Curr Opin Allergy Clin Immunol 2006; 6(1):62-66.

22. Schwartz DA, Donham KJ, Olenchock SA, Popendorf WJ, Van Fossen DS, Burmeister LF, Merchant JA. Determinants of longitudinal changes in spirometric function among swine confinement operators and farmers. Am J Respir Crit Care M ed 1995; 151(1):47-53.

23. Wang $X R$, Zhang $H X$, Sun $B X$, Dai $H L, H$ ang JQ, Eisen EA, Wegman DH, Olenchock SA, Christiani DC. A 20-year follow-up study on chronic respiratory effects of exposure to cotton dust. Eur Respir J 2005; 26(5):881-886.

24. Michel O, Kips J, Duchateau J, Vertongen F, Robert $L$, Collet $H$, Pauwels R, Sergysels R. Severity of asth$\mathrm{ma}$ is related to endotoxin in house dust. Am J Respir Crit Care M ed 1996; 154(6 pt 1):1641-1646.

25. Remes ST, Iivanainen K, Koskela H, Pekkanen J. Which factors explain the lower prevalence of atopy amongst farmers' children? Clin Exp Allergy 2003; 33(4):427-434.

26. Von Mutius E, Braun-Fahrlander C, Schierl R, Riedler J, Ehlermann S, Maisch S, Waser M, Nowak D. Exposure to endotoxin or other bacterial components might protect against the development of atopy. Clin Exp Allergy 2000; 30(9):1230-1234.
27. Eduard W, Omenaas E, Bakke PS, Douwes J, Heederik $D$. Atopic and non-atopic asthma in a farming and a general population. Am J Indust M ed 2004; 46(4):396-399.

28. Portengen L, Preller L, Tielen M, Doekes G, Heederik D. Endotoxin exposure and atopic sensitization in adult pig farmers. J Allergy Clin Immunol 2005; 115(4):797-802.

29. Liebers $V$, Raulf-H eimsoth $M$, Bruning T. Health effects due to endotoxin inhalation. Arch Toxicol 2008; 82(4):203-210.

30. Liu AH. Endotoxin exposure in allergy and asthma: reconiling a paradox. J Allergy Clin Immunol 2002; 109(3):379-392.

31. National Library of Medicine. M edline; 2006. [accessed 2009 July 16]. Available: http://www.ncbi. nIm.nih.gov/sites/entrez

32. McCarthy EF. The toxins of William B. Coley and the treatment of bone and soft-tissue sarcomas. Iowa Orthop J 2006; 26:154-158.

33. Coley WB. Treatment of inoperable malignant tumors with the toxins of erysipelas and the Bacillus prodigiosus. Trans Am Surg Assn 1894; (12):183-212.

34. Mueller $\mathrm{H}$. Tumor necrosis factor as an antineoplastic agent: pitfalls and promises. Cell Mol Life Sci 1998; 54(12):1291-1298.

35. Shear MJ, Perrault A. Reactions of mice with primary subcutaneous tumors to the injection of a hemorrhage-producing bacterial polysaccharide. J Natl Cancer Inst 1944; 4:461-468.

36. Shear MJ, Turner FC. Chemical treatment of tumours; isolation of hemorrhagic-producing fraction from Serratia marcescens (Bacillus prodigious) culture filtrate. J Natl Cancer Inst 1943; 4:81-87.

37. Carswell EA, Old LJ, Kassel RL, Green S, Fiore N, Williamson $B$. An endotoxin-induced serum factor that causes necro-sis of tumors. Proc Natl Acad Sci USA 1975; 72(9):3666-3670.

38. Clark IA. How TNF was recognized as a key mechanism of disease. Cytokine Growth Factor Rev 2007; 18(3-4):335-343.

39. Spriggs DR, Sherman ML, Michie $H$, Arthur KA, Imamura K, Wilmore D, Frei E, 3rd, Kufe DW. Recombinant human tumor necro-sis factor administered as a 24-hour intravenous infusion: a phase 1 and pharmacologic study. J Natl Cancer Inst 1988; 80:1039-1044.

40. Ghezzi $P$, Cerami A. Tumor necrosis factor as a pharmacological target. Mol Biotechnol 2005; 31(3):239-244.

41. Andreani V, Gatti G, Simonella L, Rivero V, Maccioni M. Activation of Toll-like receptor 4 on tumor cells in vitro inhibits subsequent tumor growth in vivo. Cancer Res 2007; 67(21):10519-10527.

42. Chicoine MR, Won EK, Zahner MC. Intratumoral injection of lipopolysaccharide causes regression of sub cutaneously implanted mouse glioblastoma multiforme. N eurosurgery 2001; 48(3):607-615.

43. Kuramitsu Y, Nishibe M, Ohiro Y, M atsushita K, Yuan L, Obara M, Kobayashi M, Hosokawa, M. A new synthetic lipid A analog, ON O-4007, stimulates the production of tumor necrosis factor-alpha in tumor tissues, resulting in the rejection of transplanted rat hepatoma cells. Anticancer Drugs 1997; 8(5):500-508. 
44. M orita S, Yamamoto M, Kamigaki T, Saitoh Y. Synthetic lipid $A$ produces antitumor effect in a hamster pancreatic carcinoma model through production of tumor necrosis factor from activated macrophages. Kobe J Med Sci 1996; 42(4):219-231.

45. Lange JH. An experimental study of anti-cancer properties of aerosolized endotoxin: application to human epidemiological studies. J O ccup M ed Toxicol 1992; (1):377-382.

46. Won EK, Zahner MC, Grant EA, Gore P, Chicoine $M R$. Analysis of the antitumoral mechanisms of lipopoly-saccharide against glioblastoma multiforme. Anticancer Drugs 2003; 14(6):457-466.

47. De Bono JS, Dalgleish AG, Carmichael J, Diffley J, Lofts FJ, Fyffe D, Ellard S, Gordon RJ, Brindley CJ, Evans TR. Phase I study of ONO-4007, a synthetic analogue of the lipid A moiety of bacterial lipopoly-saccharide. Clin Cancer Res 2000; 6(2):397405.

48. Engelhardt R, M ackensen A, Galanos C. Phase I trial of intravenously administered endotoxin (Salmonella abortus equi) in cancer patients. Cancer Res 1991; 51(10):2524-2530.

49. Goto S, Sakai S, Kera J, Suma Y, Soma GI, Takeuchi S. Intradermal administration of lipopolysaccharide in treatment of human cancer. Cancer Immunol Immunother 1996; 42(4):255-261.

50. Otto F, Schmid P, Mackensen A, Wehr U, Seiz A, Braun M, Galanos C, M ertelsmann R, Engelhardt R. Phase II trial of intravenous endotoxin in patients with colorectal and non-small cell lung cancer. Eur J Cancer 1996; 32A(10):1712-1718.

51. Henderson V, Enterline PE. An unusual mortality experi-ence in cotton textile workers. J Occup M ed 1973; 15(9):717-719.

52. M erchant JA, Ortmeyer C. Mortality of employees of two cotton mills in North Carolina. Chest 1981; 79(4 Suppl):6S-11S.

53. Hodgson JT, Jones RD. Mortality of workers in the British cotton industry in 1968-1984. Scand J Work Environ Health 1990; 16(2):113-120.

54. Wernli KJ, Ray RM, Gao DL, Thomas DB, Checkoway $\mathrm{H}$. Cancer among women textile workers in Shanghai, China: overall incidence patterns, 19891998. Am J Indust M ed 2003; 44(6):595-599.

55. Levin LI, Gao YT, Blot WJ, Zheng W, Fraumeni JF $J$ r. Decreased risk of lung cancer in the cotton textile industry of Shanghai. Cancer Res 1987; 47(21):5777-5781.

56. Szeszenia-Dabrowska N, Wilczynska U, Strzelecka A, Sobala W. Mortality in the cotton industry workers: results of a cohort study. Int J Occup M ed Environ $\mathrm{H}$ ealth 1999; 12(2):143-158.

57. Mastrangelo G, Fadda E, Rylander R, Milan G, Fedeli $U$, Rossi di Schio M, Lange JH. Lung and other cancer site mortality in a cohort of Italian cotton mill workers. Occup Environ Med 2008; 65(10):697-700.

58. Koskela RS, Klockars M, Järvinen E. Mortality and disability among cotton mill workers. $\mathrm{Br}$ J Ind $\mathrm{Med}$ 1990; 47(6):384-391.

59. Kuzmickiene I, Stukonis M. Lung cancer risk among textile workers in Lithuania. J O ccup M ed Toxicol 2007; 2:14; doi:10.1186/1745-6673-2-14 [Online 16 Nov 2007].
60. M astrangelo G, Fedeli U, Fadda E, M ilan G, Lange $\mathrm{JH}$. Epidemiologic evidence of cancer risk in textile industry workers: a review and update. Toxicol Ind H ealth 2002; 18(4):171-181.

61. Blair A, Sandler DP, Tarone R, Lubin J, Thomas K, Hoppin JA, Samanic C, Coble J, Kamel F, Knott C, Dosemeci M, Zahm SH, Lynch CF, Rothman N, Alavanja MCR. M ortality among participants in the agricultural health study. Ann Epidemiol 2005; 15(4):279-285.

62. Lee E, Burnett CA, Lalich N, Cameron LL, Sestito JP. Proportionate mortality of crop and livestock farmers in the United States, 1984-1993. Am J Ind $M$ ed 2002; 42(5):410-420.

63. Laakkonen A, Pukkala E. Cancer incidence among Finnish farmers, 1995-2005. Scand J Work Environ H ealth 2008; 34(1):73-79.

64. Lange JH, M astrangelo G, Fedeli U, Fadda E, Rylander $\mathrm{R}$, Lee $\mathrm{E}$. Endotoxin exposure and lung cancer mortality by type of farming: is there a hidden dose-response relationship? Ann Agric Environ Med 2003; 10(2):229-232.

65. M astrangelo G, Marzia V, M arcer G. Reduced lung cancer mortality in dairy farmers: is endotoxin exposure the key factor? Am J Ind M ed 1996; 30(5):601609.

66. M astrangelo G, Marzia V, M ilan G, Fadda E, Fedeli $\mathrm{U}$, Lange $\mathrm{JH}$. An exposure-dependent reduction of lung cancer risk in dairy farmers: a nested casereferent study. Indoor Built Environ 2004; 13:35-43.

67. Pukkala E, Notkola V. Cancer incidence among Finnish farmers, 1979-93. Cancer Causes Control 1997; $8(1): 25-33$.

68. Reif J, Pearce N, Fraser J. Cancer risks in N ew Zealand farmers. Int J Epidemiol 1989; 18(4):768-774.

69. M astrangelo G, Grange JM, Fadda E, Fedeli U, Buja A, Lange JH. Lung cancer risk: effect of dairy farming and the consequence of removing that occupational exposure. Am 」 Epidemiol 2005; 161(11):1037-1046.

70. Stark AD, Chang HG, Fitzgerald EF, Riccardi K, Stone RR. A retrospective cohort study of cancer incidence among New York State Farm Bureau members. Arch Environ Health 1990; 45(3):155-162.

71. Wang $Y$, Lewis-Michl EL, H wang SA, Fitzgerald EF, Stark AD. Cancer incidence among a cohort of female farm residents in New York State. Arch Environ $\mathrm{H}$ ealth 2002; 57(6):561-567.

72. Gunnarsdóttir H, Rafnsson V. Cancer incidence among I celandic farmers 1977-1987. Scand J Soc M ed 1991; 19(3):170-173.

73. Schroeder JC, Tolbert PE, Eisen EA, Monson RR, Hallock M F, Smith TJ, Woskie SR, Hammond SK, Milton DK. M ortality studies of machining fluid exposure in the automobile industry. IV: A casecontrol study of lung cancer. Am J Indust M ed 1997; 31(5):525-533.

74. Alavanja MC, Dosemeci M, Samanic C, Lubin J, Lynch CF, Knott C, Barker J, Hoppin J, Sandler D, Coble J, Thomas K, Blair A. Pesticides and lung cancer risk in the agricultural health study cohort. Am J Epidemiol 2004; 160(9):876-885.

75. Laakkonen A, Verkasalo PK, Nevalainen A, Kauppinen T, Kyyronen P, Pukkala El. Moulds, bacteria and cancer among Finns: an occupational cohort study. O ccup Environ M ed 2008; 65(7):489-493. 
76. Baccarelli A, Khmelnitskii O, Tretiakova M, Gorbanev S, Lomtev A, Klimkina I, Tchibissov V, Averkina $O$, Rice $C$, Dosemeci M. Risk of lung cancer from exposure to dusts and fibers in Leningrad Province, Russia. Am J Ind M ed 2006; 49(6):460-467.

77. Astrakianakis G, Seixas NS, Camp JE, Christiani DC, Feng Z, Thomas DB, Checkoway H. Modeling, estimation and validation of cotton dust and endotoxin exposures in Chinese textile operations. Ann O ccup H ygiene 2006; 50(6):573-582.

78. Chang CK, Astrakianakis G, Thomas DB, Seixas NS, Ray RM, Gao DL, Wernli KJ, Fitzgibbons ED, Vaughan TL, Checkoway H. Occupational exposures and risks of liver cancer among Shanghai female textile workers: a case-cohort study. Int J Epidemiol 2006; 35(2):361-369.

79. De Roos AJ, Ray RM, Gao DL, Wernli KJ, Fitzgibbons ED, Ziding F, Astrakianakis G, Thomas DB, Checkoway $\mathrm{H}$. Colorectal cancer incidence among female textile workers in Shanghai, China: a casecohort analysis of occu-pational exposures. Cancer Causes Control 2005; 16(10):1177-1188.

80. Gold LS, De Roos AJ, Ray RM, Wernli K, Fitzgibbons ED, Gao DL, Astrakianakis G, Feng Z, Thomas $D$, Checkoway $H$. Brain tumors and occupational exposures in a cohort of female textile workers in Shanghai, China. Scand J Work Environ Health 2006; 32(3):178-184.

81. Li W, Ray RM, Gao DL, Fitzgibbons ED, Seixas NS, Camp JE, Wernli KJ, Astrakianakis G, Feng Z, Thomas $D B$, Checkoway $H$. Occupational risk factors for pancreatic cancer among female textile workers in Shanghai, China. Occup Environ M ed 2006; 63(12):788-793.

82. Li W, Ray RM, Gao DL, Fitzgibbons ED, Seixas NS, Camp JE, Wernli KJ, Astrakianakis G, Feng Z, Thomas DB, Checkoway H. Occupational risk factors for nasopharyngeal cancer among female textile workers in Shanghai, China. Occup Environ Med 2006; 63(1):39-44.

83. Ray RM, Gao DL, Li W, Wernli KJ, Astrakianakis G, Seixas NS, Camp JE, Fitzgibbons ED, Feng Z, Thomas DB, Checkoway H. Occupational exposures and breast cancer among women textile workers in Shanghai. Epidemiology 2007; 18(3):383-392.

84. Wernli KJ, Fitzgibbons ED, Ray RM, Gao DL, Li W, Seixas NS, Camp JE, Astrakianakis G, Feng Z, Thomas DB, Checkoway $H$. Occupational risk factors for esophageal and stomach cancers among female textile workers in Shanghai, China. Am J Epidemiol 2006; 163(8):717-725.

85. Wernli KJ, Ray RM, Gao DL, Fitzgibbons ED, Camp JE, Astrakianakis G, Seixas N, Wong EY, Li W, De Roos AJ, Feng Z, Thomas DB, Checkoway H. Occupational exposures and ovarian cancer in textile workers. Epidemiology 2008; 19(2):244-250.

86. Wong EY, Ray R, Gao DL, Wernli KJ, Li W, Fitzgibbons ED, Feng Z, Thomas DB, Checkoway $H$. Reproductive history, occupational exposures, and thyroid cancer risk among women textile work-ers in Shanghai, China. Int Arch Occup Environ Health 2006; 79(3):251-258.

87. Schmidt C. Immune system's Toll-like receptors have good opportunity for cancer treatment. J Natl Cancer Inst 2006; 98(9):574-575.
88. Tzianabos AO, Wetzler LM. Cellular communication. In: Pier GB, Lyczak JB, Wetzler LM, editors. Immunology, infection, and immunity. Washington, DC: ASM Press; 2004. p. 343-369.

89. Poltorak A, HeX, Smirnova I, Liu MY, Van Huffel C, Du X, Birdwell D, Alejos E, Silva M, Galanos C, Freudenberg $M$, Ricciardi-Castagnoli $P$, Layton $B$, Beutler B. Defective LPS signaling in $\mathrm{C} 3 \mathrm{H} / \mathrm{HeJ}$ and C57BL/10ScCr mice: mutations in TIr4 gene. Science 1998; 282(5396):2085-2088.

90. Heine $H$, Rietschel ET, UImer AJ. The biology of endotoxin. M ol Biotechnol 2001; 19(3):279-296.

91. Werling D, Jungi TW. TOLL-like receptors linking innate and adaptive immune response. Vet Immunol Immunopathol 2003; 91(1):1-12.

92. Lapa e Silva JR, Possebon da Silva MD, Lefort J, Vargaftig BB. Endotoxins, asthma, and allergic immune responses. Toxicology 2000; 152(1-3):31-35.

93. Hong S, Qian J, Yang J, Li H, Kwak LW, Yi Q. Roles of idio-type-specific T cells in myeloma cell growth and survival: Th1 and CTL cells are tumoricidal while Th2 cells promote tumor growth. Cancer Res 2008; 68(20):8456-8464.

94. Maraveyas A, Baban B, Kennard D, Rook GA, Westby $M$, Grange JM, Lydyard P, Stanford JL, Jones $M$, Selby $P$, Dalgleish AG. Possible improved survival of patients with stage IV AJCC melanoma receiving SRL 172 immunotherapy: correlation with induction of increased levels of intracellular interleukin-2 in peripheral blood lymphocytes. Ann Oncol 1999; 10(7):817-824.

95. Klein A, Zhadkewich M, Margolick J, Winkelstein J, Bulkley G. Quantitative discrimination of hepatic reticulo-endothelial clearance and phagocytic killing. J Leukocyte Biol 1994; 55(2):248-252.

96. Fearns C, Kravchenko VV, Ulevitch RJ, Loskutoff DJ. Murine CD14 gene expression in vivo: extramyeloid synthesis and regulation by lipopolysaccharide. J Exp M ed 1995; 181(3):857-866.

97. Matsumura T, Ito A, Takii T, Hayashi H, Onozaki $K$. Endotoxin and cytokine regulation of Toll-like receptor (TLR) 2 and TLR4 gene expression in murine liver and hepatocytes. J Interferon Cytokine Res 2000; 20(10):915-921.

98. Su GL, Freeswick PD, Geller DA, Wang Q, Shapiro RA, Wan YH, Billiar TR, Tweardy DJ, Simmons RL, Wang SC. Molecular cloning, characterization, and tissue distribution of rat lipopolysaccharide binding protein: evidence for extrahepatic expression. J Immunol 1994; 153(2):743-752.

99. Martin TR, Mathison JC, Tobias PS, Leturcq DJ, Moriarty AM, M aunder RJ, Billiar TR, Tweardy DJ, Simmons RL, Wang SC. Lipopolysaccharide binding protein enhances the responsiveness of alveolar macrophages to bacterial lipopolysaccharide: implications for cytokine production in normal and injured lungs. J Clin Invest 1992; 90(6):2209-2219.

100. Schumann RR, Leong SR, Flaggs GW, Gray PW, Wright SD, Mathison JC, Tobias PS, Ulevitch, RJ. Structure and function of lipopoly-saccharide binding protein. Science 1990; 249(4975):1429-1431.

101. Ryan LK, Karol MH. Release of tumor necrosis factor in guinea pigs upon acute inhalation of cotton dust. Am J Resp Cell M ol Biol 1991; 5(1):93-98. 
102. Jagielo PJ, Thorne PS, Watt JL, Frees KL, Quinn TJ, Schwartz DA. Grain dust and endotoxin inhalation challenges produce similar inflammatory responses in normal subjects. Chest 1996; 110(1):263-270.

103. O'Grady N P, Preas HL, Pugin J, Fiuza C, Tropea $M$, Reda D, Banks SM, Suffredini AF. Local inflammatory responses following bron-chial endotoxin instillation in humans. Am J Respir Crit Care $M$ ed 2001; 163(7):1591-1598.

104. Wang Z, Larsson K, Palmberg L, M almberg P, Larsson $\mathrm{P}$, Larsson $\mathrm{L}$. Inhalation of swine dust induces cytokine release in the upper and lower airways. Eur Respir J 1997; 10(2):381-387.

105. Michel O, Nagy AM, Schroeven M, Duchateau J, Neve J, Fondu P, Sergysels R. Dose-response relationship to inhaled endotoxin in normal subjects. Am J Respir Crit Care Med 1997; 156(4 pt 1):11571164.

106. Larsson KA, Eklund AG, Hansson LO, I saksson $B M, M$ almberg PO. Swine dust causes intense airways inflammation in healthy subjects. Am J Respir Crit Care M ed 1994; 150(4):973-977.

107. Mackensen A, Galanos C, Wehr U, Engel hardt R. Endotoxin tolerance: regulation of cytokine production and cellular changes in response to endotoxin application in cancer patients. EurCytokine N etw 1992; 3(6):571-579.

108. Mattsby I, Rylander R. Clinical and immunological findings in workers exposed to sewage dust. J Occup M ed 1978; 20(10):690-692.

109. Palmberg $L$, Larssson BM, M almberg $P$, Larsson $K$. Airway responses of healthy farmers and nonfarmers to exposure in a swine confinement building. Scand J Work Environ Health 2002; 28(4):256-263.

110. Gordon T. Dose-dependent pulmonary effects of inhaled endotoxin in guinea pigs. Environ Res 1992; 59(2):416- 426 .

111. Bohnhorst J, Rasmussen T, M oen SH, Flottum M, Knudsen L, Borset M, Espevik T, Sundan A. Tolllike receptors mediate prolifration and survival of multiple myeloma cells. Leukemia 2006; 20(6):11381144.

112. Puntoni M, Marra D, Zanardi S, Decensi A. Inflammation and cancer prevention. Ann Oncol 2008; 19(Suppl 7):vii225-vii229.

113. Schottenfeld D, Beebe-Dimmer J. Chronic inflammation: a common and important factor in the pathogenesis of neoplasia. CA Cancer J Clin 2006; 56(2):69-83.

114. Britton S, Papp-Szabo E, Simala-Grant J, Morrison L, Taylor DE, Monteiro M A. A novel Helicobacter pylori cell-surface polysaccharide. Carbohydr Res 2005; 340(9):1605-1611.
115. Bosshart $\mathrm{H}$, Heinzelmann $\mathrm{M}$. Targeting bacterial endotoxin: two sides of a coin. Ann N Y Acad Sci 2007; 1096:1-17.

116. Dranoff G. Cytokines in cancer pathogenesis and cancer therapy. Nat Rev 2004; 4(1):11-22.

117. Lin WW, Karin M. A cytokine-mediated link between innate immunity, inflammation, and cancer. J Clin Invest 2007; 117(5):1175-1183.

118. $M$ anda $T$, Shimomura K, Mukumoto $S$, Kobayashi K, M izota T, Hirai O, M atsumoto S, Oku T, Nishigaki $\mathrm{F}$, M ori J, Kikuchi H. Recombinant human tumor necrosis factor-alpha: evidence of an indirect mode of antitumor activity. Cancer Res 1987; 47(14):3707-3711.

119. Suter $E$, Kirsanow EM . H yperreactivity to endotoxin in mice infected with Mycobacterium: induction and elicitation of the reaction. Immunology 1961; 4:354-365.

120. Cross AS. Endotoxin tolerance-current concepts in historical perspective. J Endotoxin Res 2002; 8(2):83-98

121. Gioannini TL, Teghanemt A, Zarember KA, Weiss JP. Regulation of interactions of endotoxin with host cells. J Endotoxin Res 2003; 9(6):401-408.

122. Chen $R$, Alvero AB, Silasi DA, M or G. Inflammation, cancer and chemoresistance: taking advantage of the Toll-like receptor signaling pathway. Am J Reprod Immunol 2007; 57(2):93-107.

123. M umm JB, Oft M. Cytokine-based transformation of immune surveillance into tumor-promoting inflammation. Oncogene 2008; 27(45):5913-5919.

124. Spaan S, Schinkel J, Wouters IM, Preller L, Tielemans $\mathrm{E}, \mathrm{Nij}$ ET, Heekerik D. Variability in endotoxin exposure levels and consequences for exposure assessment. Ann Occup Hyg 2008; 52(5):303-316.

125. Boffetta P. Endotoxins in lung cancer prevention. J Natl Cancer Inst 2007; 99(5):339.

Received 1 December 2008 Accepted 7 M ay 2009 